\title{
Guanine nucleotides stimulate NADPH oxidase in membranes of human neutrophils
}

\author{
R. Seifert, W. Rosenthal and G. Schultz \\ Institut für Pharmakologie, Freie Universität Berlin, Thielallee 69/73, D-1000 Berlin 33, Germany
}

Received 14 July 1986

\begin{abstract}
In the chain of events by which chemotactic peptides stimulate NADPH oxidase-catalyzed superoxide formation in human neutrophils, the involvements of a pertussis toxin-sensitive guanine nucleotide-binding protein ( $\mathrm{N}$-protein), mobilization of intracellular calcium and protein kinase $\mathrm{C}$ stimulation have been proposed. Superoxide formation was studied in membranes from human neutrophils; NADPH oxidase was stimulated by arachidonic acid in the presence of neutrophil cytosol. Fluoride and stable GTP analogues, such as GTP $\gamma \mathrm{S}$ and GppNHp, which all activate N-proteins, enhanced NADPH oxidase activity up to 4fold. GDP $\beta$ S inhibited the effect of GTP $\gamma$ S. These data suggest that NADPH oxidase is regulated by an $\mathrm{N}$-protein, independent of an elevation of the cytoplasmic calcium concentration.
\end{abstract}

Neutrophil NADPH oxidase Guanine nucleotide-binding protein Arachidonic acid

\section{INTRODUCTION}

Binding of the chemotactic peptide, FMLP, to neutrophil membrane receptors induces several cellular responses including superoxide formation [1], release of arachidonic acid, phospholipase Ccatalyzed degradation of phosphatidylinositol 4,5-bisphosphate to diacylglycerol and inositol 1,4,5-trisphosphate as well as mobilization of intracellular calcium $[2,3]$. All these FMLP-induced events involve a pertussis toxin-sensitive $\mathrm{N}$-protein [2-4]. As PMA, which is an activator of protein kinase $C$, stimulates NADPH oxidase in intact neutrophils [1], it is widely assumed that activation

Abbreviations: AppNHp, adenylyl imidodiphosphate; ATP $\gamma$ S, adenosine 5'-O-(3-thiotriphosphate); FMLP, $\quad N$-formyl-L-methionyl-L-leucyl-L-phenylalanine; GDP $\beta \mathrm{S}$, guanosine $5^{\prime}-O$-(2-thiodiphosphate); GppNHp, guanylyl imidodiphosphate; GTP $\gamma \mathrm{S}$, guanosine 5 - $O$-(3-thiotriphosphate); $\mathrm{N}$-protein, guanine nucleotide-binding protein; PMA, phorbol 12-myristate 13-acetate of NADPH oxidase is mediated by protein kinase C-catalyzed phosphorylation of the oxidase or a regulatory component $[1,5]$. There is recent evidence indicating that NADPH oxidase activation by FMLP may not necessarily be linked to phosphoinositide turnover or activation of protein kinase $\mathrm{C}$, as a transient increase in the intracellular calcium concentration is not sufficient for FMLPinduced NADPH oxidase activation [6]. In addition, inhibitors of protein kinase $C$ block PMAbut not FMLP-induced superoxide formation $[7,8]$. Furthermore, in calcium-depleted human neutrophils primed with subthreshold concentrations of PMA, FMLP activates NADPH oxidase in the absence of phosphoinositide hydrolysis [9].

We studied the regulation of NADPH oxidase in membranes from unstimulated human neutrophils. These investigations were prompted by the finding that arachidonic acid activates superoxide formation in a cell-free system consisting of the particulate $48000 \times g$ fraction and the cytosolic fraction from human neutrophils [10]. We report here that stable GTP analogues 
stimulate NADPH oxidase activity, suggesting the direct involvement of an $\mathrm{N}$-protein in the regulation of this enzyme.

\section{MATERIALS AND METHODS}

Human neutrophils were isolated by dextran sedimentation and centrifugation through FicollHypaque (Biochrom, Berlin) and disrupted by nitrogen cavitation. Neutrophil membranes and cytosol were isolated by centrifugation on discontinuous Percoll gradients (Pharmacia, Uppsala) [11], harvested and stored at $-80^{\circ} \mathrm{C}$.

NADPH oxidase activity of neutrophil membranes was determined by measuring the linear rate of superoxide dismutase-inhibitable ferricytochrome $c$ reduction at $27.5^{\circ} \mathrm{C}[10]$. The assay mixture $(500 \mu \mathrm{l})$ contained $2-7 \mu \mathrm{g}$ neutrophil membrane protein, $30-170 \mu \mathrm{g}$ cytosolic protein, $500 \mu \mathrm{M}$ NADPH, $10 \mu \mathrm{M}$ FAD, $100 \mu \mathrm{M}$ ferricytochrome $c$, $3.4 \mathrm{mM} \mathrm{MgCl}_{2}, 200 \mu \mathrm{M} \mathrm{ATP}, 500 \mu \mathrm{M}$ EGTA and $50 \mathrm{mM}$ triethanolamine- $\mathrm{HCl}, \mathrm{pH}$ 7.0. Although the specific activity of NADPH oxidase varied to some extent between membrane preparations as observed by Jones et al. [12], qualitatively comparable results were obtained in all preparations analyzed.

For pertussis toxin treatment of neutrophils, purified neutrophils were suspended at $8 \times 10^{7}$ cells $/ \mathrm{ml}$ in carbogen-saturated buffer $(138 \mathrm{mM}$ $\mathrm{NaCl}, 6 \mathrm{mM} \mathrm{KCl}, 1 \mathrm{mM} \mathrm{MgSO} 4,1.1 \mathrm{mM} \mathrm{CaCl}_{2}$, $0.1 \mathrm{mM}$ EDTA, $1 \mathrm{mM} \mathrm{Na} \mathrm{HPO}_{4}, 5 \mathrm{mM} \mathrm{NaHCO} 3$, $5.5 \mathrm{mM}$ glucose, and $20 \mathrm{mM}$ Hepes, $\mathrm{pH} 7.4$ ) and incubated for $3 \mathrm{~h}$ at $37^{\circ} \mathrm{C}$ with pertussis toxin (1 $\mu \mathrm{g} / \mathrm{ml}$ ) or its carrier. Cells were then washed twice in the same buffer, and membranes were isolated.

Protein determination was performed according to Lowry et al. [13]. NADPH, FAD, guanine and adenine nucleotides were from Boehringer Mannheim (Mannheim, FRG). Ferricytochrome $c$ (Type III), superoxide dismutase and arachidonic acid (grade I, $99 \%$ pure, from porcine liver) were obtained from Sigma (Taufkirchen, FRG). A stock solution of $16 \mathrm{mM}$ arachidonic acid in $100 \%$ ethanol was prepared under nitrogen and stored at $-20^{\circ} \mathrm{C}$.

\section{RESULTS}

Original registrations of superoxide formation are shown in fig.1. Arachidonic acid $(16 \mu \mathrm{M})$ stimulated superoxide generation in neutrophil membranes in the presence of neutrophil cytosol; there was a lag time of 1-4 min from addition of arachidonic acid to reaching a constant rate of superoxide formation, depending on the membrane preparation used. In the absence of neutrophil cytosol, NADPH oxidase was not activated by arachidonic acid. Addition of the stable GTP analogue, GTP $\gamma \mathrm{S}(10 \mu \mathrm{M})$, which activates $\mathrm{N}$-proteins [14], 2 min prior to or with arachidonic acid enhanced the rate of superoxide production about 3-fold.

This effect was specific for non-hydrolyzable GTP analogues (fig.2). GTP $\gamma s$ and GppNHp stimulated superoxide formation about 4-fold; the effect of GTP $\gamma \mathrm{S}$ was half-maximal at $1 \mu \mathrm{M}$, GppNHp was 2 orders of magnitude less potent. GTP, ATP $\gamma$ S and AppNHp at up to $300 \mu \mathrm{M}$ had no effect. GDP $\beta$ S did not stimulate NADPH oxidase activity but competitively inhibited the stimulatory effect of GTP $\gamma \mathrm{S}$ (fig.3): $10 \mu \mathrm{M}$ GDP $\beta$ S caused half-maximal inhibition of the superoxide formation observed in the presence of $1 \mu \mathrm{M}$ GTP $\gamma$ S. Fluoride, which is another potent activator of N-proteins [14], activates superoxide generation [15] and calcium mobilization [16] in intact neutrophils. In the presence of aluminium (5 $\left.\mu \mathrm{M} \mathrm{Al}_{2}\left(\mathrm{SO}_{4}\right)_{3}\right)$, which is necessary for fluoride activation of $\mathrm{N}$-proteins [17], fluoride $(10 \mathrm{mM})$ enhanced NADPH oxidase activity about 4-fold, an effect comparable to that obtained with the

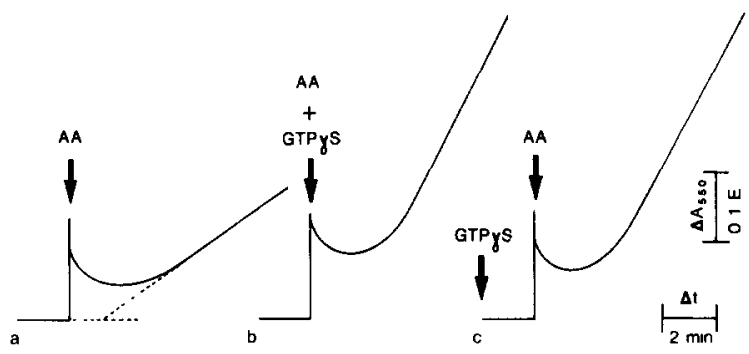

Fig.1. Time courses of superoxide generation in human neutrophil membranes. Superoxide formation was determined with $2 \mu \mathrm{g}$ membrane protein in the presence of 30 $\mu \mathrm{g}$ neutrophil cytosol. The intersection of the dashed lines represents the lag time required for NADPH oxidase activation, defined from extrapolation of the absorbance curve to zero. AA indicates addition of arachidonic acid $(16 \mu \mathrm{M}), \mathrm{GTP}_{\gamma} \mathrm{S}$ the addition of GTP $\gamma \mathrm{S}(10 \mu \mathrm{M})$. 


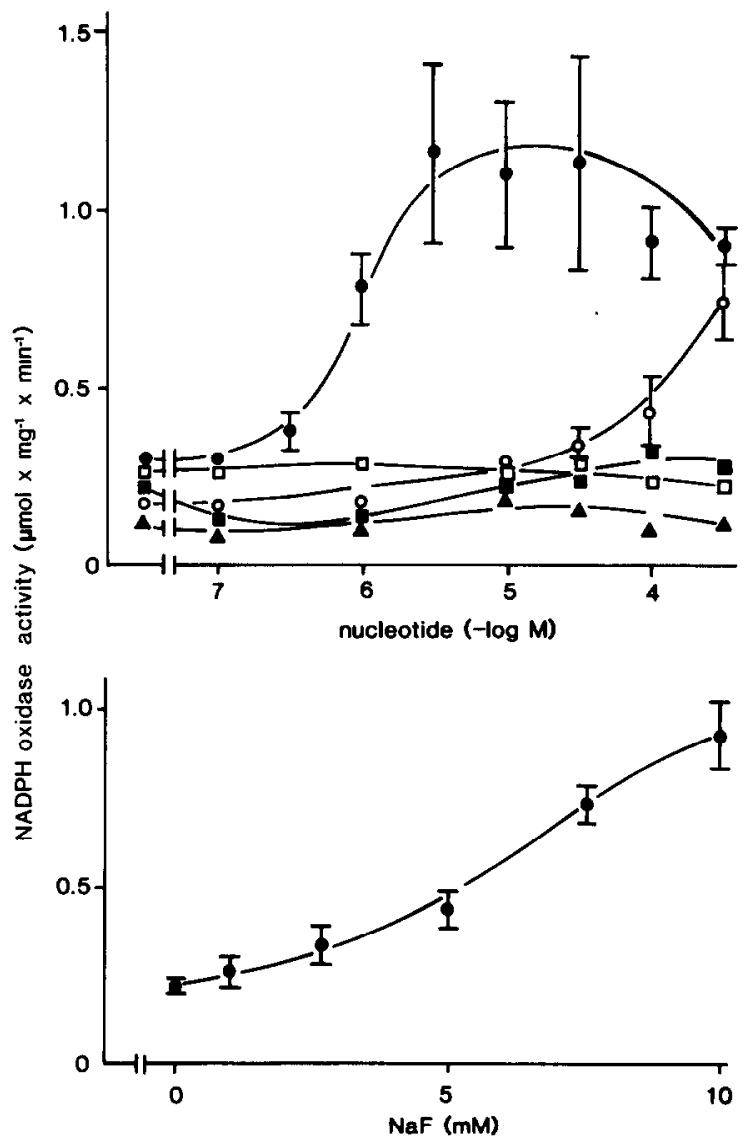

Fig.2. Influence of guanine and adenine nucleotides and of fluoride on NADPH oxidase activity. Upper panel: nucleotides were added to the assay mixture, containing $2 \mu \mathrm{g}$ membrane protein and $30 \mu \mathrm{g}$ cytosolic protein, 2 min prior to arachidonic acid $(16 \mu \mathrm{M})$. Data represent the means \pm SE of 3 determinations. $(\bullet)$ GTP $\gamma$,

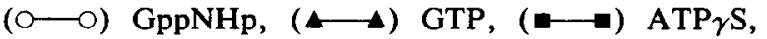
$(\square-\square)$ AppNHp. Lower panel: $\mathrm{NaF}$ at the indicated concentrations and $5 \mu \mathrm{M} \mathrm{Al}_{2}\left(\mathrm{SO}_{4}\right)_{3}$ were added prior to arachidonic acid $(16 \mu \mathrm{M})$. The assays contained $2 \mu \mathrm{g}$ membrane protein and $30 \mu \mathrm{g}$ cytosol protein. Data are the means \pm SE of 6 determinations.

non-hydrolyzable GTP analogues (see (fig.2).

In analogy to the adenylate cyclase system [18], the stimulatory effect of GTP $\gamma$ S was not reduced in membranes obtained from neutrophils pretreated with pertussis toxin (fig.4). In contrast to the adenylate cyclase system, in which the effects of GTP $\gamma$ S are significantly delayed following pertussis toxin treatment, the lag time required for NADPH oxidase activation by arachidonic acid

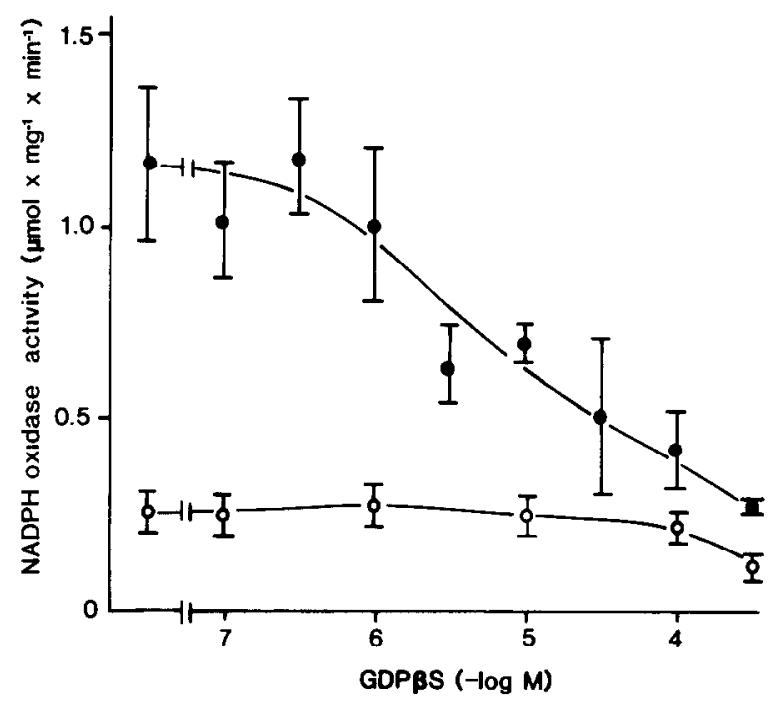

Fig.3. Influence of GDP $\beta$ S on NADPH oxidase activity in neutrophil membranes. GDP $\beta$ S was added at the indicated concentrations without $(\mathrm{O}-\mathrm{O})$ and with concomitant addition of $1 \mu \mathrm{M} \mathrm{GTP} \gamma \mathrm{S}(\bullet) 2$ min prior to arachidonic acid $(16 \mu \mathrm{M})$. The assays contained $2 \mu \mathrm{g}$ membrane protein and $30 \mu \mathrm{g}$ cytosolic protein. Data are the means $\pm \mathrm{SE}$ of 3 determinations.

and GTP $\gamma \mathrm{S}$ in membranes from pertussis toxintreated neutrophils was not changed.

\section{DISCUSSION}

It was recently shown that NADPH oxidase in neutrophil membranes is stimulated by arachidonic acid in the presence of neutrophil cytosol [10]. We report here that this stimulation of the enzyme is increased several-fold by stable GTP analogues and fluoride, known stimulators of $\mathrm{N}$-proteins. The present findings suggest that NADPH oxidase represents a new N-proteinregulated effector system. The oxidase represents the first $\mathrm{N}$-protein-controlled enzyme that can be monitored by a photometric method.

In contrast to the current opinion that chemotactic peptides indirectly stimulate NADPH oxidase in the course of neutrophil activation [1], our results suggest a more direct involvement of an $\mathrm{N}$-protein in the regulation of NADPH oxidase. The identity of the cytosolic cofactor required for NADPH oxidase activation in neutrophil membranes and the mechanism by which arachidonic 


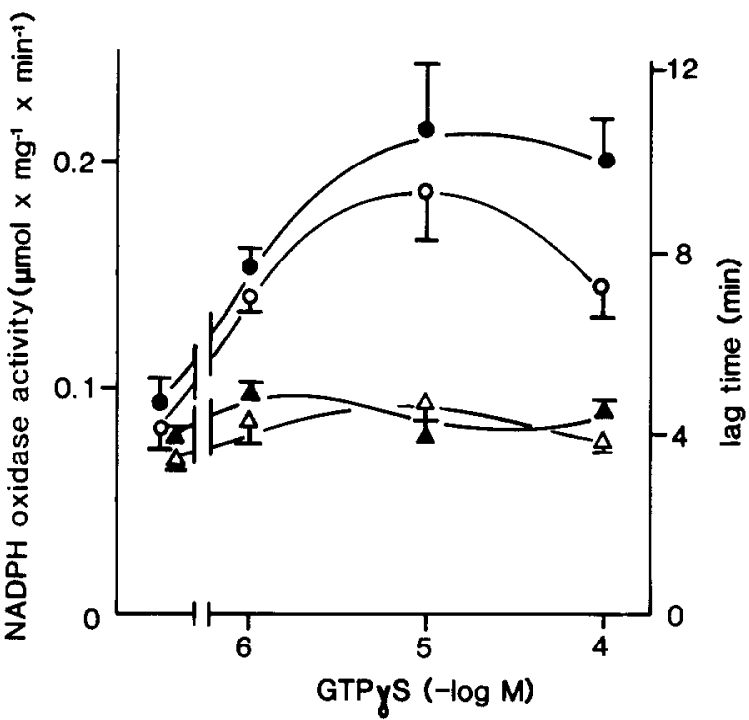

Fig.4. Effect of GTP $\gamma$ S on NADPH oxidase activity in membranes obtained from pertussis toxin-treated neutrophils. GTP $\gamma$ S was added to membranes obtained from neutrophils treated with pertussis toxin or its carrier. The assay mixture contained $7 \mu \mathrm{g}$ membrane protein and $170 \mu \mathrm{g}$ cytosolic protein; the reaction was started with arachidonic acid $(16 \mu \mathrm{M})$. Data are means \pm SE of 4 determinations. NADPH oxidase activity is indicated by circles, the lag time from addition of arachidonic acid to reaching maximal velocity (determined as described in fig.1) by triangles. Closed symbols represent pertussis toxin-treated neutrophil membranes, open symbols the controls.

acid stimulates superoxide generation are unknown. Since arachidonic acid stimulates cytosolic protein kinase $C[19,20]$, it has been supposed that protein kinase $\mathrm{C}$ may represent the cytosolic cofactor [10]. According to a recent report, an $\mathrm{N}$-protein may be involved in the activation of membrane-associated protein kinase $C$, because GTP $\gamma \mathrm{S}(10 \mu \mathrm{M})$ stimulates protein kinase $\mathrm{C}$ in membranes of rabbit peritoneal neutrophils [21]. On the other hand, arachidonic acid may interact directly with the neutrophil membrane, activating NADPH oxidase by facilitating the electron transport from NADPH to cytochrome $b_{-245}$ or the interaction of the cytosolic component with the enzyme [22]. Therefore, at present it is not yet possible to explain the mechanism by which guanine nucleotides, in concert with arachidonic acid and neutrophil cytosol, stimulate superoxide production in human neutrophil membranes.

\section{ACKNOWLEDGEMENTS}

The authors wish to thank Miss M. Wulfern for excellent technical assistance, Dr M. Yajima for providing pertussis toxin and Mrs R. Krüger for help in the preparation of the manuscript. This work was supported by the Deutsche Forschungsgemeinschaft and the Fonds der Chemischen Industrie.

\section{REFERENCES}

[1] McPhail, L.C. and Snyderman, R. (1984) in: Regulation of Leucocyte Function (Snyderman, R. ed.) Contemporary Topics in Immunobiology, vol.14, pp.247-281, Plenum, New York.

[2] Okajima, F. and Ui, M. (1984) J. Biol. Chem. 295, 13863-13871.

[3] Ohta, H., Okajima, F. and Ui, M. (1985) J. Biol. Chem. 260, 15771-15780.

[4] Lad, P.M., Olsen, C.V. and Smiley, P.A. (1985) Proc. Natl. Acad. Sci. USA 82, 869-873.

[5] Papini, E., Grzeskowiak, M., Bellavite, P. and Rossi, F. (1985) FEBS Lett. 190, 204-208.

[6] Pozzan, T., Lew, D.P., Wollheim, C.B. and Tsien, R.Y. (1983) Science 221, 1413-1415.

[7] Wright, C.D. and Hoffman, M.D. (1986) Biochem. Biophys. Res. Commun. 135, 749-755.

[8] Cooke, E. and Hallett, M.B. (1985) Biochem. J. 232, 323-327.

[9] Grzeskowiak, M., Della Bianca, V., Cassabella, M.A. and Rossi, F. (1986) Biochem. Biophys. Res. Commun. 135, 785-794.

[10] McPhail, L., Shirley, P.S., Clayton, C.C. and Snyderman, R. (1985) J. Clin. Invest. 75, 1735-1739.

[11] Borregaard, N., Heiple, J.M., Simons, E.R. and Clark, R.A. (1983) J. Cell. Biol. 97, 52-61.

[12] Jones, H.P., Ghai, G., Petrone, W.F. and McCord, J.M. (1982) Biochim. Biophys. Acta 714, 152-156.

[13] Lowry, O.H., Rosebrough, N.J., Farr, A.L. and Randall, R.J. (1951) J. Biol. Chem. 193, 265-275.

[14] Gilman, A.G. (1984) J. Clin. Invest. 73, 1-4.

[15] Curnutte, J.T., Babior, B.M. and Karnovsky, M.L. (1979) J. Clin. Invest. 63, 637-647.

[16] Strnad, C.F. and Wong, K. (1985) Biochem. Biophys. Res. Commun. 133, 161-167.

[17] Bigay, J., Deterre, P., Pfister, C. and Chabre, M. (1985) FEBS Lett. 191, 181-185. 
[18] Jakobs, K.H., Aktories, K. and Schultz, G. (1984) Eur. J. Biochem. 140, 177-181.

[19] Murakami, K. and Routtenberg, A. (1985) FEBS Lett. 192, 189-193.

[20] McPhail, L.C., Clayton, C.C. and Snyderman, R. (1984) Science 224, 622-625.
[21] Huang, C.K. and Devanney, J.F. (1986) Fed. Proc. $45,1136$.

[22] Bromberg, Y. and Pick, E. (1985) J. Biol. Chem. 260, 13539-13545. 